\title{
LISTY SW. AUGUSTYNA OBRAZEM JEGO DUSZY
}

Każdy list w rozumieniu tzw. Demetriosa jest "wizerunkiem duszy autora korespondencji"1. W nawiązaniu do tego określenia przyjrzymy się duszy Augustyna w zwierciadle jego epistolografil ${ }^{2}$. Posłużymy się $w$ tym celu wyrażeniami Biskupa Hippony badającego własną duszę. Już "Wyznania" przekonują nas o jego wielkiej zdolności 1 upodobaniu do autorefleksji i introspekcji. Niemniej waźnym źródłem są tu jego "Solilokwia". Również w innych dziełach, listach 1 kazaniach spowiada się często Augustyn Bogu 1 swoim braciom ${ }^{3}$. Jest jednak zasadnicza róznica między "Wyznaniami" 1 11stami, bo w swej korespondencji Biskup Hippony przekazuje o sobie wiele danych, ale skierowanych do swoich adresatów, co niewątpliwie utrudnia odczytanie stanów jego duszy. Równieź zawarte tam rady, upomnienia 1 pociechy, od których roi się w jego korespondencji, pozwalają przybliżyé się do. jego psychiki. Tak na przykład analogicznie do swych "Wyznán" pisał do Januarego:

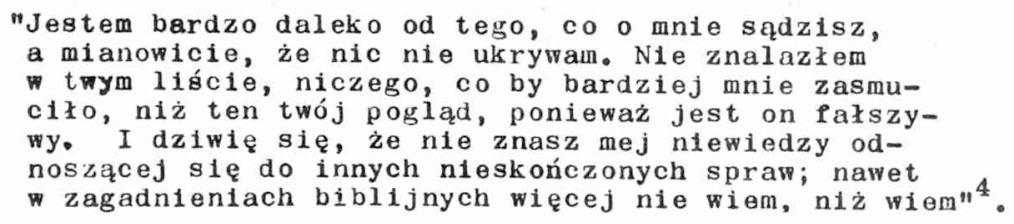

1 Demetrios, o wyrazaniu s1ę, I wiek; por. J. Schnayder, Wstęp, w: Antologia listu antycznego, Wrockaw $1959 / \mathrm{BN}$ II $117 /$, S. III.

2 M. Pellegrino, Fisionomia spirituale, w: S. Agostino, Le lettere, I, Roma 1969 , ss. XLIV-LXXVII; W. Thimme, Augustin ein Lebens und Charakterbild auf Grund seiner Briefe, Gottingen 1910.

3 Por. Confessiones X 1, 1, CSEL 33, 226.

4 Epistola 55, 38, CSEL 34, $212 / \mathrm{r} .400 /$. 
Miłość Boga i bliźniego wywołuje więc doznania w duszy sugustyna, otwierające jej tajniki Boże 1 wyjaśniające mu trudne teksty Pisma Éwiętego. W liście do Paulina i Terazji stwierdza, ze z Paulinem "woli mówić o tym, czyn będziemy, niż o tym, czym jesteśmy"5. W innym znów liście do Nebrydiusza czytamy, że dusza jest nieśmiertelna ${ }^{6}$, a szczęście polega na radości, jaką nas obdarzają byty duchowe ${ }^{7}$. Mimo że Augustyn roznawia ze sobą, to owe roztrząsania kończą się zwykle modlitwą odprawianą wieczorem ${ }^{8}$. Najbardziej interesującym jest w tym względzie jego 4 list, w którym opisuje swój wzlot do Boga odbywający się przy Bożej pomocy do najprawdziwszych bytów duchowych: to wzniesienie jest wejściem wiebie ${ }^{9}$.

List 10, będącym 5 do Nebrydiusza, odsłania nam znów duszę Augustyna: wyznaje w nim, że skupienie pozwoliło mu upodobnić się do Boga ${ }^{10}$. Jest ono w tym wypadku synonimem samotności $i$ koniecznym warunkiem od strony ludzkiej tego upodobnienia. G. Folliet zwrócił kiedyś uwagę na wpływy platońsko-plotyńskie, a szczególnie porfiriańskie, uwidaczniające się w powyższym sformułowaniu ${ }^{11}$. Przypomniał on przy tym skargi wypowiedziane przez Biskupa Hippony na Porfiriusza, który przed nawróceniem odciągał go od Chrystusa jako Słoma Wcielonego. Ten pogański mędrzec zdążał, by upodobnić się do Boga, ale z pominięciem Chrystusa, usiłując dojść do celu droga cnót. Każdy oczywiście musi uznać wpływ trzech wyilienionyci filozofów na Augustyna, nieıniej jednak pozwolimy sobie zauważyé, że chociaź od niedawna się nawrócił i przyjął chrsest/387/, to jednak tuź przed napisaniem listu do Nebrydiusza został on obdarowany laską mistycznej ekstazy całkowicie już chrześcijańskiej ${ }^{12}$. Zgadzany się z P. Henrym, że relacja wizji w Ostil przekazana jest w języku plotyńskim. Przyznajeray równiez, że Augustyn nie doszedz jeszcze do całkowicie doktrynalnego ujęcia przeżycia

5 Epistola 95, 5, CSLL 34, 510/r。405-408/.

6 Epistola 3, 4, CSisL $34,8 / \mathrm{r} .387 /$.

7 Epistola $3,3, \mathrm{CSEL} 34,7$.

8 Taniże.

9 Epistola 4, 2, CSLL 34, 10.

10 Epistola 10, 2, CSEL 34, $23 / \mathrm{r} \cdot 388-391 /$.

11 G. Folliet, "Deificari in otio", Augustin. Epistola 10, 2, "Recherches Augustiniennes" 2/1962/ 225-236.

12 Confessions IX 10, trad. et com. A. Solignac/Bibliothèque Augustinienne 13\% 191-197; z dawniejszych autorów por. P. Henry, 
mistycznego, będąc dopiero u początku własnej teologi łaski. Mimo to sam Porfiriusz nie wystarczyłby do wyjaśnienia nawet ówczesnego przeżycia upodobnienia do Boga 1 rozpoczętego pojmowania wymienionego doznania mistycznego u Augustyna.

Niewiele później, bo w 390 r. w liście napisanym do Romaniana, Augustyn zachęcał:

\footnotetext{
"Pozbądźmy się juź trosk o rzeczy zmienne, szukajmy stałych $i$ pewnych, wznosząc sie ponad ziemskie zasoby. I pszczoła bowiem ma skrzydła, by wyjść z dużego miodu, bo zabiłby on tę, która by w nim tkwiła"13.
}

Nebrydiusz w jednym ze swych listów do Augustyna/list $5 /$ zarzuca mu 1 jego współobywatelom z Tagasty, że "zbytnio się kochają". Wiemy, że to zbytnie uniłowanie swoich bliźnich i oddanie się wśród nich apostolskiemu działaniu odrywało faktycznie Augustyna od bogomyślności. Jego apostolskie obowiazki zwiększyły się jeszcze bardziej, gdy został kapłanem skierowanym do pomocy biskupa Waleriusza. Aby sprostać swym zadaniom duszpasterskim, musiał on "prosić, szukać 1 kołatać, czyli modlić się, czytać i opłakiwać"14. Jako neoprezbiter zaklinał wówczas Valeriusza: "wiem, że Pan nie gardzi ową miłością błagającą w mej intencji, a przyjmuje ją jako o_iarę przyjemną"15. W słowach tych Augustyn zaklinał swojego biskupa, by modlił się za niego 1 dał mu jeszcze trochę czasu na głębsze poznanie Pisma św. By go zaś nie przerazić odwlekaniem z nin współpracy, pisał: "Może nawet i w krótszym czasie, niź prosiłea, Bóg zapozna mnie ze zbawiennymi radaini Pisma św." 16 . Wkrótce pojął owe biblijne wskazania 1 zaczał prowadzić działalność apostolską. Zdoliny był to czynić dlatego, że dzięki nodlitwie jednoczył się z bogiem:

"W ten sposób/čyli poprzez Biblię/ pouczony człowiek potrafi pędzić życie wśród bezbożnych, w wi ększym

La vision d'Ostie, Paris 1938; z autorów najnowszych por. Takeshi Kato, L'extase a deux, w: Augustinus Lexikon, Bd. 1, Stuttgart 1986, 1-6. Japoíski uezony zwraca uwage na istotny udziaz Moniki w ekstazie natki i syna.

Epistola 15, 2, CSLL 34, 36 /do Romaniana/.

14 Epistola 21, 4, CSLL 34, 52 /po Wielkanocy $391 \mathrm{r.} /$.

15 Epistola 21, 6, CSEL 34, 54. 
spokoju sumienia umrzeć i zabiegać o to, by nie utracić tego życia, do którego jedynie wzdychają chrzé́cijańskie pokorne 1 łagodne sercall17.

Oto poryw kapłańskiej duszy Augustyna do dóbr wiecznych, nie wykluczający nawet męczeństwa, zależny jednak od ciągłej modlitwy, o czym świadczy jego list poświęcony modlitwie:

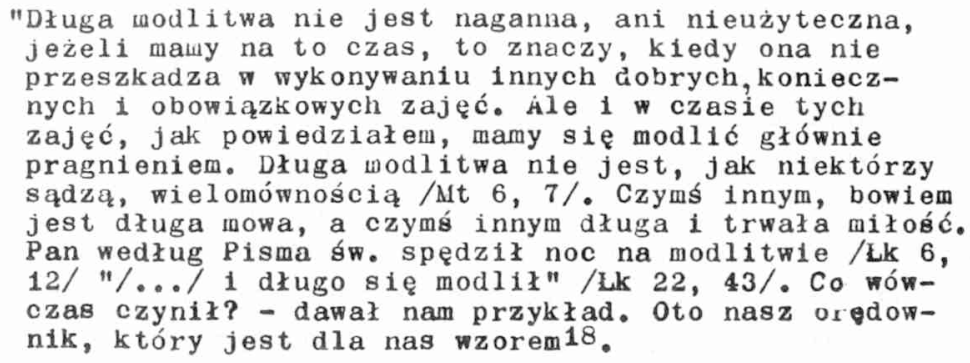

Życie apostolskie jest życiem prowadzonym pod natchnieniem $i$ kierunkiem miłości.

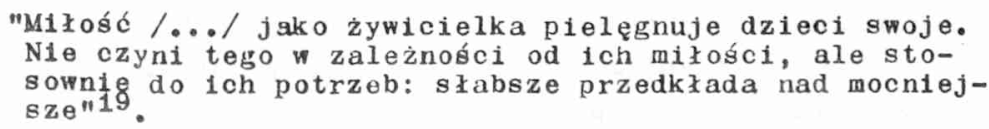

Augustyn zna 1 potwierdza skierowane do niego zdanie Paulina, że miłość wymaga męczeństwa, czyli "przeżycia śmierci ewangelicznej. Ona to dzięki dobrowolnemu oderwaniu się od spraw ziemskich wyprzedza śmierć cielesną" ${ }^{20}$. Dzieje się to wtedy, gdy z tego świata odchodzimy w zgodzie $z$ naszym sumieniem:

"Sprawa jest prosta i nie ma według naszego przekonania wątpliwości, że w tym śmiertelnym życiu

17 Epistola 21, 4, CSEL 34, 52.

18 Epistola 130, 19, CSEL 44,61-62/po r. 411/.

19 Epistola 139, 3, CSEL 44, 153 /z roku 411 do Marcelina/.

20 Por. Epistolá 94, 4, CSEL 34, 501/r.408-409/。 
winniśmy przygotowywać się wewien sposób do zycia nieśmiertelnejo. Istnieje jednak niepokojacy problem ludzi działających i szukających, takich jak ja. Polega on na tym, jak należy żyé wśród ludzi i dla tych, którzy jeszcze nie umieją żyé, umierając nie smiercia cielesniz, lecz wewnętrznym oderwaniem się od cielesnych ponęt. Często nam się wydaje, że jésli nie zgadzamy się z takimi ludźmi, co-do ich postepowania, od którego pragniemy ich odwrócić, to nie zdziałamy nic pożytecznego dla -ich zbawienia. Wóczas odczumamy, że urok tych ziemskich dóbr wślizguje sié w nas /... . wtedy nasze zbrukane dusze stają się ocięzałe 1 z wielkim mozołem 1 powolnościa wznosimy je do Boga, by brać udział w życiu zgodnym z ewangelia i umierać śmiercią ewangeliczną"21.

Augustyn zdaje sobie sprawe, że osiagnąwszy pewne sukcesy na tej drodze, wystawia się na pokusę pychy. Modlitwa jednak dodaje mu sił i chroni przed zarozumiałością. 0 tej roli miłości 1 znaczeniu modlitwy poucza nas jego korespondencja z Eudoksjuszem, do którego pisał:

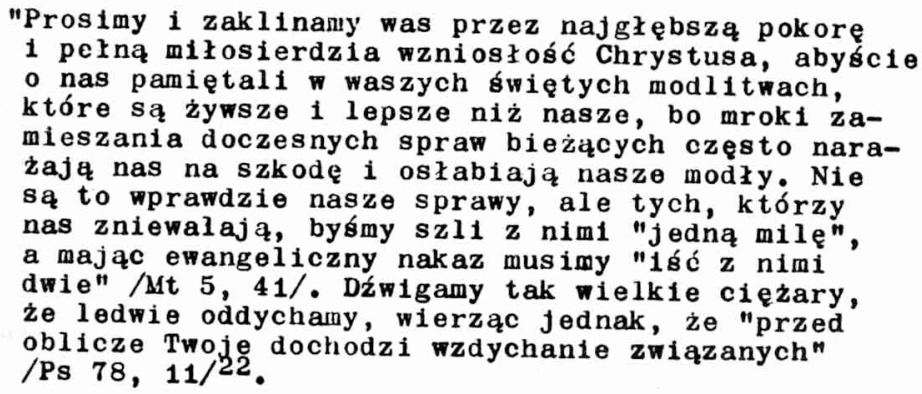

Biskup Hippony bez pokory na pokaz liczy na modły swoich bliźnich, którym się poleca. I tak na zakończenie krótkiego listu do Aureliusza, prosi go: "Módl się za mnie"23. Podobna prósbę kieruje do swoich wiernych podczas swej nieobecnoścl w Hipponie ${ }^{24}$. Nawet u kresu Jego życia,

21 Epistola 95, 2, CSEL 34, 507/r.408-409 do Paulina 1 Terazj1/.

22 Epistola 48, 1, CSEL 34, $137 / \mathrm{r}, 398 /$.

23 Epistola 174, CSEL 44, 651/r.415-416/.

24 For. Epistola 122, 2, CSEL 34, 744/r. 410/. 
na przełomie 429/430 r., brzmi modlitewne echo "Wyznań" i prośby o modły wstawiennicze, jak o tym świadczy list do komesa Dariusza:

"Przyjmij, mój synu, przyjmij męzu dobry 1 chrześcijaninie niepozorny, lecz pełen Chrystusowej miłości księgę molch "Wyznań", o którą prosiłeś: przesyłam ci Ja zgodnie z twym zyczeniem. Poprzez nia popatrz na mnie, kim jestem, by mnie zbytnio nie chwalić. Przyjrzyj się mnie w świetle relacji zawartej w "Wyznaniach", abyś mnie nie chwalił ponad to,kim jestem /.../ 1 przekonaj się kim byłem sam w sobie i dzięki sobie. A jeżeli we mnie coś ci się podoba, to chwal ze mną Tego, którego chwały szukałem, a nie swojej, bo swej nie chciałem, gdyż on nas uczynił, a nie my sami siebie /Ps 99, 3/. Myśmy narazili się na zgubę, a on nasz Stwórca nas uratował. Gdy tam mnie znajdziesz, módl się za mnie, abym. się nie sprzeniewierzył, ale doszedł do celu. Módl się synu, módl się. Prośbę tę wypowiadam z głębi duszy i świadomie. Nie uważaj tego za przesadną pokorę. Nie myśl, że nie jesteś tego godny, jakoby to przekraczało twoje zasługi. Nie modląc się zaś wojej intencji, pozbawiasz mnie bardzo dużej pomocy. Nie tylko ty, ale wszyscy, którzy dzięki twoim słowom nas pokochali, módlcie się za nas. Przekaź im moją prośbę. Ponieważ zaś macie dla nas wiele szacunku, uznajcie naszą prośbę za polecenie 1 wypełnijcie je, albo posłuchajcie naszego nakazu. Módlcie się za nas. Czytaj Pismo św., a znajdzieszw nim analogiczná prośbę samych apostołów, przywódców trzody naszego Pana oraz ich nakaz skierowany do słuchaczy. Ja z pewnością spełnię twoja prośbę i będę modlił się za ciebie, odwzajemniając się modlitwą pełną miłości. Jesteśmy pasterzami waszymi, a wy trzoda Bożą / 1 P 5, 2/. Rozważc1e to 1 zobaczcie, że nasze niebezpieczeństwa są większe niz wasze 1 módlcie się za nas. Niechaj Pan udzieli nam 1 wam tego, byśmy zdali dobrą sprawe z naszej troski o was. Najwyzszemu Pasterzowi 1 naszej wspólnej Głowie. Obyśmy również uniknęli pochlebstw tego świata bardziej niebezpiecznych niz jego przykrośc1, chyba, że pokój jego temu sprzyja. o co zas według wezwania Apostoła mamy sie modlić? - "Abyśmy ciche 1 spokojne zycie wiedli we mszelkiej poboźnośc1 1 m1łości" / $/ 1$ Tm 2, 2/. Módlcie się zatem, abyśmy mieli życie ciche i spokojne we wszelkiej poboźności i miłości; podobnie, jak my w tej intencji modlimy sie za was, tak $i$ wy w tej samej za nas składajcie prośby. Gdziekolwiek bowiem jesteście, 1 gdziekolwiek my jesteśmy - On tam jest wszędzie 1 do niego nal eżym" 25 . 
Augustyn więc nie tylko modlił się sam za siebie i przeżywał szczyty mistycznego zjednoczenia z ojcem, ale modlił się równieź za swe owieczki - za orzyjaciół 1 za wrogów. Nożna powiedzieć, że w tej modlitwie za bliskich przejawia się jeoo dusza, zgodnie z podana na wstępie Demetriosowa definicją listu.

W innych znów listach Biskup Hippony dziękuje za łaskę nawrócenia i cieszy się z przyjęcia chrztu przez Gawiniana, lekarza Dioskora i komesa Peregryna 26 . Stwierdza, że prawdziwa przyjaźn to nie tylko, jak ją określa Cyceron"27, "zgodność we wszystkich sprawach boskich i ludzkich z źyczliwością 1 wajemną miłością", ale zgodność oparta na Chrystusie Jezusie Panu naszym, który jest naszym najprawdziwszym pokojem ${ }^{28}$. Gdzie indziej znów cieszy się i dziękuje Bogu za odzyskanie dawnego przyjaciela Marcjana ${ }^{29}$ oraz modil się za bliskich sobie, by porzucili błędy przeciw wierze i stali się jej głosicielani:
"Radujemy się razem w wielkim uniesieniu ludu, żeś w naszej obecności powrócil do prawdziwej 1 katolic- kiej wiary. Smucimy sie jeszcze z lenistwa twoich domowników w pójściu za twoim przykładen/.../ Módlmy się do Boga, aby podporządkowali się naszym wskazaniom. Ufamy miłosierdziu Bożenu, że niedługo list Pelegryna, naszego brata 1 kolegi w biskupstwie, jak równié twoja, kochany przyjacielu, odpowiedź napełni radością nasze serca, a "język nasz unie-
sieniem" /Ps 125, 2/30.

Nawet gdy uciekał się do pomocy państwa przeciwko cirkumcelionom, wzywał do modlitwy za ich kapłanów Saturnina 1 Eufratesa, którzy niedawno powrócili ze schizmy do jedności oraz zachęcał ich, by się modlili za tych, którzy jeszcze sa smutni, aby ich słabość doznała uzdrowienia: "Wszak ich trapi słabość na sicutek długiego nałogu"31.

26 Wzmiankuje o tyn 1 ist 227 , napisany według A. Mandouze /Prosopographie de 1'Afrique chrétienne 303-533, Paris 1981, 528-529/ w latach $388 / 430$.

27 Laelius de amicitia 6, 20, tłum. K. Kumaniecki/Literatura Rzymska. Okres cyceroński, Warszawa 1977, 369/.

28 Epistola 258, 4, CS $37,608$.

29 List 258 pisany po nawróceniu adresata Marcjana w r. 386 lub raczej współczesny sakrze biskupiej Augustyna, która się odbyŁa r. 395 /A. Mandouze, dz.cyt., 691-692/.

30 Epistola 170,10 , CSEL 44, 630-631/r.416-418 do lekarza Maksyma/.

31 Epistola 142, 4, CSEL 44, 249-250. 
Zaledwie znikła groźba donatyzmu, a pojawił się groźny dla całej owczarni Chrystusowej pelagianizm. I w tej sytuacji prosi ok. $417 \mathrm{r}$. Paulina o modlitwę w intencji nawrócenia zwolenników błędu PelagiuSza:

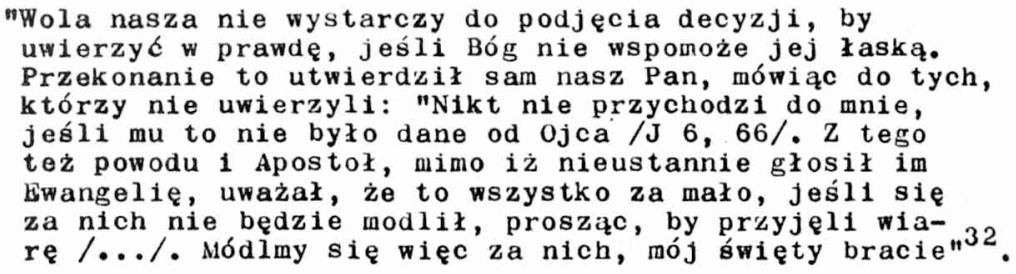

Charaktérystyczną cechą życia modlitwy św. Augustyna, jego apostolskich 1 intelektualnych wysiłków w zgłębianiu dostępnych dla człowieka rządów Opatrznoścł Bożej, dopuszczającej zło w świecie, jest pełne 1 ochotne poddanie się woli Bożej. Uwidacznia się to jasno jego korespondencj1 z poboznaz niewiastą Maksymą, czyli w 11scie 264, który według ostatnich badań pochodzi z 418 roku ${ }^{33}$ :

"Bóg tylko pozwala na istnienie złych, jeśli wie, że jest to pożyteczne 1 wystarcza do pouczenia 1 doświadczenia jego świętego domu. I w ten sposób pociesza nasz smutek wywołany przez złych ludzi, bo 1 sam żal, Jakiego z ich powodu doznajemy, podnosi nas, a ich trwających w swym złu obciąża. Radość jaką odczuwamy z poprawy niektórych nawróconych oraz z ich zespolenia ze świętąspołecznościa nie da się porównać do żadnego Innego wesela. Dlatego teź Pismo św. zawiera następuJąca przestroge: "Synu, jeśli będziesz mądry, to bedziesz nim dla siebie i dla swoich bliskich. Jeśli staniesz się zły, sam poniesiesz szkodę"/Prz 9, 12 LXX/. Gdy radujesz sięz myśli o wiernych $i$ sprawiedliwych, to ich cnota im 1 nam pomaga. Gdy niewierni 1 nieprawi ludzie nas zasmucaja, ich zło 1 nasz smutek im samym szkodza. Nam zaś u Boga bardzo wiele pomaga 34 dobroczynna miłośc, którą wyrażamy język1em 1 modłami ${ }^{34}$.

Modlitwa wymaga równiez studiów, ale koniecznat jest w niej także pomoc Boża, jak na przykład w rozwiazywaniu, h zagadnień

32 Epistola 186, 38, CSEL 57, 77-78/r. 417/.

33 Por. A. Mandouze, dz.cyt., 717 .

34 Epistola 264, 2, CSEL 57, 636 . 
łacińskiego przekładu psałterza: "Ty pragniesz - pisał do Audaksa skarbu mądrości, a otrzymałeś go mniej, niź chciałeś. Ja o niego proszę codziennie żebrząc na modlitwie o jego odrobinę, a zaledwie go otrzymuję" ${ }^{35}$. W innym znów liście autor oczekuje przede wszystkim pomocy z nieba do rozwiązania trudnego biblijnego zagadnienia:

\footnotetext{
"Wydaje mi się, ze większy wpływ na to dociekanie wywiera życie badaczy, niż najlepsze dyskusje. Bo ci, którzy się nauczyli od Jezusa Chrystusa być cichymi 1 pokornymi sercem /Mt 11, 29/, więcej zyskują modląc się, niz czytając i słuchając. Nie trzeba jednak zaniechać posługiwania się dyskusja, lecz skoro ten, "kto sadzi 1 kto podlewawypełnił" swój obowiązek, to resztę należy zostawié Temu, który "wzrost daje" $/ 1$ Kor $3,7 / 36$.
}

Mimo, że według Augustyna wiara wyprzedza zrozumienie, to jednak źczy on Konsencjuszowi, by próbował tę wiarę zrozumieć:

\begin{abstract}
"A ty, najmilszy, módl się gorąco 1 wytrwale, by Pan udzielił ci pojmowania wiary. W ten sposób zewnętrzne pouczenia, jakich udziela ci pilny nauczyciel i znawca, będą owocne, ponieważ ani ten "kto sadzi nie jest czymś, ani ten kto poullewa, ale Bóg, który wzrost daje" /1 Kor 3, 7/, do którego mówimy: "Ojcze nasz, któryś jest w niebie /Mt 6, 9/. Powyższą prośbę zanosimy do Boga nie dlatego, zeby tu był, a tam Go nie było - wszak On cały jest wszędzie swa duchowa obecnościa - ale przez to wyrażgmy, że jest on w tych, których pobożność wspiera"37.
\end{abstract}

B1skup Hippony przypomina tu wymienionemu adresatowi blask prawdy oświecającej ${ }^{38}$. W liście 266 skierowanym do Florentyny w r. 408/409 czytamy o Mistrzu wewnętrznym, który przebywając w jej młodym sercu przekonuje ją, że "prawdziwe są dopiero co przekazane słowa"/1 Kor $3,7 /^{39}$.

35 Ep1stola 261, 1, CSEL 57, 618/do Audaksa/.

36 Epistola 147, 1 , CSEL 44, 274-275/r.413-414/。

37 Epistola 120, 14, CSEL 34,716/po r. $410 /$.

38 Por. Epistola 120,6, CSEL 34, 708-709.

39 Epistola 266, 4, CSEL 57, 658 . 
Autor wreszcie nieśmiertelnego le.jtmotiwu w "Wyznaniach"40 o niespokojnym sercu ludzkim i zaspakajaniu jego potrzeb przez Boga, musi dzięki światłu Bożemu 1 własnemu doswiadczeniu uzyskanemu na modlitwie uznać jej znaczente w czasie swej ostrej walki z pelagianiznem. Dysputa z Pelagiuszem 1 jego uczniami jest ściśle powiązana nie tylko.z wypracowaniem aurustyriskiej teologii łaski,lecz także z uwypukleniem wielkiej wagi modlitwy. Modlitwa bowier jest, jak pisze Augustyn w 177 liście z 416 r. do papieża Innocentego I, najczystszym dowodem konieczności łaski. Dzięki łasce wypraszanej na modlitwie, dokonuje sie dzieło zjednoczenia z Bogiem. Biskup IIippony jest zdecydowanie przekonany, co tez mocno podkreśla w wymienionym liście do Innocentego I, że modlitwa jest potrzebna każdemu chrześcijaninowi, by nie uległ pokusie: "Modlimy się, byśmy mogli pokonać pokusę, aby duch Boży, od którego otrzymaliśmy zadatek /2 Kor 1, 22/, wspomagał naszą niemoc/ $\mathrm{Rz} 8,26 / " 41$. W innya znów liście zwraca się do sprzyjającego Pelagiuszowi Jana,biskupa Jerozolimskiego, w następujących słowach:

\footnotetext{
"Wykaż nu /Pelagiuszowi/konieczność uznania łaski Bożej, którą, jak wiadomo, z całą pewnością wyznawali święci Boży, gdy sami prosili Pana, by wypełnic Jego rozkazy. Uczynisz to zarówno przez napomnienie ze wzgiędu na jego zbawienie, które powinno być w Chrystusie, jak równiez modląc się za niego. Swięci otrzymali rozkaz, by ukazać istnienie ich woli, proszą zaś rozkazodawce, by wsparł jej niemoc"42.
}

Kościół więc modli się za tych, którzy nie wierzą, bo Bóg jest dawcą wiary. Zanosi tez modły w intencji wierzących, przez co przypomina, że Bóg udziela daru wytrwania. Zwróćmy wreszcie uwagę na list Augustyna do Julianny, matxi młodej Demetriady, która przybrała welon zakonny, gdzie przestrzega córkę 1 matkę przed wpływem Pelagiusza:

\footnotetext{
"Widzisz dobrze, jak należy wystrzegać się wielkiego niebezpieczeństwa, jakimjkonsekwencjam1 grożą te słowa. Brzıią zaś one następująco: "Te dobra moga byé tylko w Tobie"43. Słowa te brzmia zachęcajaco,
}

40 Confessiones I 1, CSLL 33, 1: "Inquietum est cor nostrum, donec requiescat in te".

41 Épistola 177,4, CSEL 44, 672.

42 Epistola 179, 5, CSEL 44, 694.

43 Epistola Pelagi ad Demetriadem 11, PL 33, 1107. 


\begin{abstract}
najprawdziwiej 1 całkowicie pokrzepiaja. Dalsze wypowiedzi tego autora o tych wartościach, że pochodzą od ciebie samej, wyrażają pogląd zatruty jadem fałszu. Nie daj Boże, by dziewica poświęcona Chrystusow chętnie ich słuchała. Ona rozumie własne ubóstwo ludzklego serca 1 dlatego ozdabia sie klejnotami swego Oblubieńca. O tych duchowych bogactwach słuchaj raczej Apostola, który mówi: "/.../ A skarb ten mamy waczyniach glinianych, aby wyniosłość dzieła naszego była dziełem potęgi Bozej, a nie naszej"//2 Kor 4, 7/ /.../. Nie dziwcie się, że te skarby należą do wás, nie pochodzac od was; o chlebie bowiem powszednim tez mówimy, że jest naszym, a mimo to prosimy o niego posługując się formułą" daj nam", by nie uważano, że sobie go zawdzięczany" 44 .
\end{abstract}

Możemy przypuszczać, że wspomniana dziewica oddana Bogu oraz ugruntowana w karności i pokorze chrześcijańskiej, po przeczytaniu powyższych słów błagała Go, by nie było u niej przekonania, dzięki któremu uważałaby, że posiada coś, z czego mogłaby się chlubić jako ze smej własności, a nie z czegoś otrzymanego od Pana / 1 Kor 1, 31/: od Najwyższego bowiem otrzymała wszystkie dary, które ją czynia dobrą. Bo "jej dusza chlubié się będzie w Panu" /Ps 33, 3/, który nasycił dobrami jej pragnienia/Ps 102, 5/. On sam natchnaz dziewice pragnieniem, by nie cillubiła się jakimś dobrem, jakoby go nie otrzymała $/ 1$ Kor $4,7 /$.

Na zakończenie naszych rozważań o modlitwie worespondencji św. Augustyna trzeba sięgną́ do napisanego po 411 roku 130 listu do Proby. Biskup Hippony określa w nim jej przedmiot następująco: "Módl się o życie szczęśliwe"45. Szczęśliwym zaś, jego zdaniem, jest ten, "który ma wszystko, co chce 1 nie pragnie niczego nieodpowiedniego. Jeźeli zaś tak jest, to spójrz, jakie jest to odpowiednie pragnienie" ${ }^{46}$. A czego człowiek winien należycie pragnąć? - życia wiecznego ${ }^{4}$. Człowiek wówczas żyje naleźycie i poźytecznie na ziemi, jeżeli zbiera zasługi na życie wieczne 48 .

44 Epistola 188, 5-6, CSEL 57, 123-124/r. 417-418/.

45 Epistola 130, 9, CSEL 44,50.

46 Tamze, 11, CSEL 44, 52 .

47 Tamże, 14, CSEL 44, 55.

48 Tamże. 
Do tego też życia, w którym żyje się dla Boga 1 z Boga, należy odnieść bez wątpliwości pozostałe dobra, upragnione pożytecznie $i \operatorname{godziwie} 49$. W zwierciadle prywatnych listów św. Augustyna widać więc jasno, że jego dusza jest spragniona Boga, w którym znajduje swój spoczynek, bo on zaspakaja wszystkie jego dążenia.

Ks. Wacław Eborowicz - Pelplin

DE S. AUGUSTINI EPISTOLIS UTI IPSIUS ANIMAE IMAGINE

/Argumentum/

Hac in dissertatiuncula auctor in fundamento Demetril sententiae "epistolam imaginem animae auctoris esse" S. Augustini animam ac vitam spiritualem, quae ex lllius epistolis patent, exponit.

49 Épistola 14, CSEL 44, 55. 